\title{
INNOVATION AND CREATIVITY SANGGABUANA BANDUNG UNIVERSITY IN PRINTING SUPERIOR HUMAN RESOURCES
}

\author{
Y. Ony Djogo \\ Sanggabuana University, Bandung, Indonesia \\ ony.djogo@usbypkp.ac.id
}

\begin{abstract}
Competitive advantage is the ability of an organization to formulate a strategy that places it in a favorable position with respect to other organizations. It is not easy to make HR a source of competitive advantage for a company because it is related not only to ability and expertise, but also to personal factors such as values, perceptions, attitudes, personality and individual willingness to advance. Human resources are said to have a competitive advantage if they have unique skills and personalities that match the company personality where they work. Innovations and strategies for developing human resources in managing organizations are a solution to the economic business challenges.
\end{abstract}

Keywords: Innovation, Creativity, Excellent Human Resources

\section{A. Introduction}

The success of an organization or company is determined by human resources, because HR is an important asset in determining the success of an organization. All potential human resources are very influential on the organization's efforts to achieve its goals. Employees as HR in the company are an important asset to achieve predetermined goals. In general, an effort is needed to continuously improve the knowledge, education or skills, discipline and mental attitude of employees at each level.
The development of the world economy and the structural changes that have occurred in various aspects have created challenges as well as opportunities for the development of the business world. One thing that is a prerequisite for overcoming existing challenges and taking advantage of business opportunities that arise is increasing competitiveness. Strategic competitiveness is achieved when a company succeeds in formulating and implementing an appropriate strategy. Today companies are trying to increase their competitiveness by building and jointly seeking new sources of 
technology and skills that can lead to the formation of new corporate structures.

The key to success in being able to survive in the midst of competition lies in the company's ability to develop its competitive advantage. One of the company's strategies in developing competitive advantage is through innovation. According to Wahyono (2002) the main purpose of innovation is to meet market demand so that the product of innovation is one that can be used as a competitive advantage for the company. In addition, human resource development is expected to be able to make employees as members of the organization have knowledge and expertise. This process runs in the long term in accordance with or in line with the implementation of the strategy carried out by the institution concerned.

Development aims to prepare the competencies / abilities of employees needed for long-term positions in anticipation of possible changes in knowledge, technology and insights without being planned or planned in accordance with the achievement of the institutional mission.
Competitive advantage is the ability of an organization to formulate a strategy that places it in a favorable position with respect to other organizations. It is not easy to make HR a source of competitive advantage for a company because it is related not only to ability and expertise, but also to personal factors such as values, perceptions, attitudes, personality and individual willingness to advance. Human resources are said to have a competitive advantage if they have unique skills and personalities that match the company personality where they work, especially for Postgraduate graduates of Sanggabuana University, Bandung. The formulation of the problem in this research is howPostSanggabuana University Bandung Post-Innovation and Creativity in Creating Excellent Human Resources?

\section{B. Basic Theory}

\section{Definition of Human Resource Management (MSDM)}

There are several definitions or definitions of Human Resource Management (HRM) from experts. Among them are: According to Malayu, Hasibuan MSDM is the 
science and art of managing the relationship and role of the workforce to be effective and efficient in helping the realization of the goals of the company, employees, and society. According to Edwin B. Flippo: Personnel management is planning, organizing, directing and controlling the procurement, development, compensation, integration, maintenance and stopping of employees, with the aim of realizing the goals of the company, individuals, employees and society and according to Dale Yoder : is a provider of leadership and direction for employees in their work or employment relationship.

\section{Innovation Concept}

Owned and developed in an entrepreneur or company for the development and success of a business. Through the innovation process creates added value for goods and services which then creates various advantages including competitive advantages. According to Hills (2008) innovation is as an idea, practice or object that is considered new by an individual or other user unit. Meanwhile, according to Suryana (2003) innovation is the ability to apply creativity in order to solve problems and opportunities to improve and enrich life.

Organizational innovation can be interpreted broadly and varies in various ways. Innovation is the provision of new solutions that can provide value to consumers. From some of the definitions above, it can be concluded that innovation is a method or process of pouring ideas and practices that are considered new to provide added value to users so that entrepreneurs or companies have different values to be able to compete with other companies.

\section{Innovation Goals and Principles}

The main objective of the innovation process is to provide and deliver better customer value. Innovation can be viewed with a structuralist approach and a process approach. The structuralist approach views innovation as a unit with fixed parameters such as technology and management practices, while the process approach views innovation as a complex process, which often involves various social groups in the 
organization. Companies can innovate in the areas of: 1) Product innovation (goods, services, ideas and places); and 2) Management innovation (work processes, production processes, finance, marketing and others).

In do innovation company need to pay attention to principles such as: analyzing opportunities, what to do to satisfy opportunities, simple and purposeful, starting small and leadership.

\section{Creativity}

Today's technological developments have created new ways of completing work in various sectors, such as manufacturing, banking, services and so on. This condition then demands creative, innovative and competitive human resources (HR).

Government institutions without creativity and innovation will result in underdeveloped organizations and their performance will always be in the public spotlight, criticism, and apathy for the institution itself. Therefore, creativity and innovation in every government agency that wants to advance must strengthen internally first, so that when internally it is strong and produces organizational products that are ready and solid, automatically when facing external problems the organization can overcome.

Organizations must instill a work culture that supports the creation of new creativity and innovation. One way is by empowering human resources to always be critical and to follow up on their critical nature with real actions to quickly solve the problems at hand. Then the attitude is given the opportunity to carry out the self-actualization process.

Today all aspects of life are required to compete to show the best, because the best will survive to remain competitive on the stage of globalization.

An organization should prepare itself to face the challenges that exist in this world full of global turmoil. For example, the very rapid development of world business has resulted in intense and tough market competition. Every day there are business people who produce and introduce their products with new creativity and innovation, so that competition is inevitable. If business actors do not try to be creative and innovative 
themselves in producing their products, then their business will be crushed by other competitors.

Indeed, people who play a big role in an organization or company. Humans are the driving force of all components in the organization, so that humans become the spearhead of the overall management of the organization.

To make changes in a positive direction, reliable humans are needed who are able to find the right and unique strategy to win the competition. As is well known, in an organization there is one element, namely human beings who are the driving force for the goals of an organization and have the most role in determining the success or failure of the organization's goals.

Human resources, or employees, play a role in planning, implementing, supervising and controlling the organization for maximum mission achievement. This is vital for humans in an organization, so that in order to run the organization well, humans must be creative.

Creative is creating new ideas or ideas that are able to produce new products that did not exist before and can be used by the community. The characteristics of a creative person include having a lot of ideas and willingness, having a spirit that likes challenges, always tries something new, and has a professional spirit. Meanwhile, what is meant by innovation is an update that aims to provide more value to a product with new ideas that are different from other products.

\section{Concept of HR Development}

\section{Strategy}

Investationthe most important thing for companies / institutions is human resources where human resources are the key to the success of the institution in order to survive and develop properly. In order for the human resources owned by the institute to contribute optimally, human resources are needed, both through education and training. There are five strategic definitions that need to be put forward, namely strategy as a plan, tactics, patterns, positions and perspectives.

The form of this strategy can be explained as follows:

a. Strategy as a plan, is a series of actions and guidelines related to the 
situation used, namely: taking action first in its implementation and developing consciously and directed.

b. Strategy as a strategy or tactic in order to trick competitors. Strategies are carried out to anticipate threats that come.

c. Strategy as a pattern is a way of localizing an organization which can be interpreted as an environment.

d. Strategy as a perspective will try to move the organization in the external environment and towards a concrete position. In this definition, strategy can be interpreted as a concept that unites individuals with organizational behavior.

According toThompson and Strickland as quoted by Hani Handoko (1995), strategy is actually a management field plan to strengthen the position of the organization, satisfy users of products or services and achieve performance targets. According to Nisjar, the objective of a strategy is to maintain or achieve a position of advantage over competitors.

WithThus, a strategy is a pattern of decisions in an organization that determine and express objectives and determine policy principles and plans in achieving these goals. The strategy according to the meaning of strategic management is an effort to maximize the competitive advantage and competitive disadvantage of an organization including its products and services as well as the consumers (customers) it serves.

The HR development strategy is a plan on how the quality of human resources that is owned can develop in a better direction, increase work ability, skills and have good loyalty to the organization or company.

Mondy \& Noe (1995: 270) states that human resource development is a management effort that is planned and carried out on an ongoing basis to improve worker competence through training, education and development programs. Strategies or steps that can be taken by companies / organizations can be in the form of scheduling training programs, providing opportunities for employees to contribute ideas, giving rewards and punishments.

\section{HR Development Strategy}


Griffin (2000) states strategy as a comprehensive plan to achieve organizational goals. Not only achieving, but the strategy is also intended to maintain the sustainability of the organization in an environment where the organization carries out development activities in the form of:

a. Organizational Development (Organization Development). Organizational development is a program to increase organizational effectiveness by integrating the desires of individuals and groups. The development of the organization itself is expected to result in cultural changes which include values, attitudes, behavior patterns, ideas, meanings, in the workplace / organization.

b. Job Group. This means that how to carry out work activities with various needs and motivations to be able to coordinate, communicate intensively with various forms of ideas, ideas, and creativity in the organization, so as to achieve common goals. The components mentioned above can also increase productivity and quality of work life / commitment to groups.

c. Education (Employees Education Development). Apparatus education, one of the HR functional strategies of an organization, seeks to provide opportunities for employees according to their own needs, abilities and way, oriented and focused on individuals and selfdevelopment. The expected results in this approach are career mobility, personality growth.

d. Employee training (Employees Training). Training aims to increase the ability of employees in carrying out tasks. The training has a short-term work target by focusing on workers who have not mastered technical / operational skills. Employee development through training activities in addition to being oriented to the short and long term. The expected results can provide knowledge and abilities for workers to improve the quality of employees in order to have a competitive advantage.

e. Analysis of training needs(Training Need Assessment). Training 
Needs Assessment (TNA) or training needs analysis is a step that is carried out before conducting training and is an integrated part of designing training to obtain a comprehensive picture of the material, time allocation for each material, and learning strategies that should be applied in the provision of training so that training is beneficial for training participants.

\section{Method of Implementation}

This service aims to improve things related to existing phenomena, namelyPost-Sanggabuana University Bandung Post-Innovation and Creativity in Creating Excellent Human Resources.

\section{Results and Discussion}

Competitive advantage basically grows from the value or benefits a company can create for its consumers. According to Porter (1993) competitive advantage is a company's benefit strategy to create more effective competition in its market. Then Lumpkin and Dess (2005) state that a competitive advantage exists when customers feel that the company's products have advantages over its competitors. So competitive advantage can be concluded that the ability obtained through the characteristics and resources of a company to have a higher performance than other companies.

Competitive advantage can be seen from the level of importance of quality to the market and classifies it into 4 (four) types of resources in value creation, namely the process of resources to reduce the company's cost structure, product resources to improve company performance, time resources to deliver value accordingly. market time, and innovation resources to influence technology. These and other resources form the creation of value in the process of developing a firm's competitive advantage.

According to Mangkuprawira (2007), the two main principles that companies need to have in order to gain competitive advantage are the value of customer perspective and product uniqueness.

a. Customer Value Viewpoint. Competitive advantage occurs when there is a customer view that they get 
a certain value from economic transactions withthe company. For this reason, all company employees must focus on customer needs and expectations. This only materializes when customers are involved in designing the process of goods or services and are encouraged to help companies design the right HRM system.

b. Corner Uniqueness. Uniqueness is characterized by goods and services that the company produces cannot easily be imitated by competitors. The characteristics of the uniqueness include:

1) Financial and economic capability.

The uniqueness that is shown by its existencethe ease of companies to obtain financial resources relatively quickly with an interest that is relatively lower than market interest. In addition, it can be in the form of the company's ability to reduce product prices that are cheaper than the price of the same product from other companies.

2) Ability to create strategic products

This type of uniqueness takes the form of the advantages of the characteristics of your product over the same products from other companies. Among others, it can be seen from the aspects of taste, size, appearance and safety of the product as well as the atmosphere of the business environment. 3) Technology and process capabilities

Company must have different characteristics in making and presenting products to customers than other companies. This is characterized by the tools usedwhether it is old or modern and is well known for its reliability among a wide range of customers. Usually the customer already has a favorite choice about the particular tools and processes he likes. Another example is the use of sophisticated equipment such as computer systems and modern production processing plant facilities.

4) Organizational skills

The uniqueness here is characterized by the company's advantages in managing organizational systems that are commensurate with customer needs. Companies, including their employees, need to be highly responsive, sensitive and adaptable in keeping up with changes in customer character, technology, supply conditions, regulations, and economic conditions. 
Thus customers will be happy to always be loyal to the company.

The company strives to maintain its competitive advantage by innovating in processes, product characteristics, and transaction methods. Competition is a fundamental challenge of business strategy. In order to survive and achieve success, companies must outperform competitors in many different ways. The company must offer its customers higher value by offering higher quality and comfort at a relatively lower price compared to competitors.

Competitive advantage generally indicates that the company can achieve higher performance than competitors in the industry by utilizing its assets and / or competencies.

Competitive advantage has the following characteristics: 1) sustainable: A company must lead its competitors in a sustainable manner or last for a long time, and will end when competitors succeed in imitating the same competitive advantage; 2) uniqueness: A company needs to have competencies that only a small number of companies have; 3 ) persistence: A company needs to lead competitors by a significant gap.

In an era that is rapidly experiencing changes like today, the competition that appears in the home industry is in an environment that is dynamic and full of uncertainty including products, prices, places, technology, raw materials, distribution, resource expertise, consumers and so on. Home industry players must create the right strategy so that the company is able to compete, maintain business life and develop it.

Competitive advantage can be realized through the creation of uniqueness in product and packaging designs, better quality of production processes, more attractive marketing, more satisfying sales services for consumers, and so on. The company's strategy in developing competitive advantage is through innovation.

Today's increasingly tight business competition makes company management have to think hard to find the right way to survive and at the same time succeed in achieving the company's management goals (profit, market share, growth, etc.). 
The ways to gain this competitive advantage have been formulated by Michael Porter are:

\section{a. Overall Low Cost Leadership.}

With this low cost strategy the company tries to make itself a producer with the highest level of efficiency and has the lowest cost level among its competitors. The characteristics of this low cost strategy include: (1) aggressive development of efficient scale facilities; (2) trying to reduce costs based on previous experience; (3) strict costs and control over overhead costs; (4) avoid burdening managerial customers; and (5) minimizing costs in all activities in the company value chain such as R\&D, services, sales and advertising.

\section{b. Differentiation.}

Companies that implement a differentiation strategy do not try to appear as the lowest cost producer, but instead produce a product that is unique so that it is easily distinguished from similar products in the market. The characteristics of this differentiation strategy include: (1) prestige and brand image; (2) technology; (3) innovation;

(4) features; (5) customer service; and (6) dealer network. c. Focus.

Companies that have a focused strategy will select a segment or segment group and adjust the strategy to serve that segment. Competitive advantage is achieved by concentrating specifically on that segment. The essence of the focus is the exploitation of a specific niche market that is different from other industries.

\section{E. Conclusion}

Innovation is one solution that companies can take to overcome competition and increase the quality of employees. Because innovation can provide effectiveness, enthusiasm and increase the quality of employees because with innovation it can be faster and more efficient, more enthusiastic about work and increased skills so that competitive advantage can be achieved and the company will get maximum performance results automatically the sustainability of the company can be maintained and goals can be achieved. reached.

Creative is creating new ideas or ideas that are able to produce new products that did not exist before and can be used by the community. The 
characteristics of a creative person include having a lot of ideas and willingness, having a spirit that likes challenges, always tries something new, and has a professional spirit.

The HR Development Strategy must be carried out as a company method or method so that its employees have quality and up-to-date information that is relevant at that time so that the company has assets in the form of a quality and competitive workforce because it is equipped with certain knowledge and skills.

Competitive advantage generally indicates that the company can achieve higher performance than competitors in the industry by utilizing its assets and / or competencies.

\section{REFERENCES}

Hasibuan, M. 2012. Human Resource Management. Jakarta. Earth Literacy.

Maulidih, S. 2012. Human Resource Management. Module at Brawijaya University. Malang: not published. Meirinia, T. 2010. Strategic Management and HR Development Strategy Towards Competitive
Advantage. Journal of Socio

Religia. Vol 9.3 May 2010.

Nazir, M. 2003. Research Methods. Jakarta. Ghalia Indonesia.

Prasetya, H 2007. Building Strategic Excellence through Strategic Alliances to Improve Company Performance. Journal of Management and Organizational Studies. Volume 4, Number 2 July, 2007.

Robbins, S. 2012. Organizational Behavior. Jakarta. Four Salemba.

Sugiyono. 2014. Qualitative and Quantitative Research Methods R \& D. Bandung. Alfabeta.

Setiawan, T 2016. Achievement of Company Excellence with HR Management. Mahardika's Journal. Sudjana, D 2012. Education Outside School Foundation and Philosophy. Bandung. Nurul Falah.

Sunarsih, N 2016). Building Competitive Advantage through Innovation and Entrepreneurship. Journal of Entrepreneurship in Multi Persefective.

Development team. (2016). Indonesian Language Guidelines. General Guidelines for Indonesian Spelling. 
Jakarta. Ministry of National

Education.

Yadiman (2018). Entrepreneurship

Supporting Entrepreneurs.

Bandung. Mujahid. 